\title{
The Translation Quality of Modality Markers in Riordan's The Blood of Olympus
}

\author{
Widyastuti \\ Universitas Negeri Surabaya \\ Surabaya, Indonesia \\ widyas@unesa.ac.id
}

\begin{abstract}
This paper attempts to examine the quality of translation by two out of three components of equivalence, that is, accuracy and acceptability through the novel. The text depicted a phenomenon of social engagement through the modality markers that are used by interactants in stating an opinion. Modality is attached to give meaning of necessity and possibility. Philosophically, this is classified into epistemic and deontic modality. The former relates to the level of certainty of a proposition's truth while the latter expresses the language user's attitudes in society such as, duty, morality, laws and rules. Besides, politeness principles which is proposed by Geoffrey Leech applied. It will be shown that the modality that the translator uses the meaning of possibility more than necessity and that these indicate the low value of modal operator.
\end{abstract}

Keywords - epistemic modality; deontic modality; Politeness Principle

\section{INTRODUCTION}

Translation is a form of intercultural communication and social act, aimed at establishing interpretative similarity between source text and the target text, governed by the principle of optimal sameness. Since the two languages and two cultures come into contact, translators have important role to transfer the work of the author to bring to mind understood by the audience. For all that, they must of course consider 'context of situation', namely, field, tenor, and mode. They are the more immediate situational context which has to do with questions about who wrote the text, when, why, for whom, and who is reading it, and for what purpose [7], similarly, Newmark [15] advocates that the purpose of the text can be as a keystone of the invariance which changes from text to text; It may be expressed through as much words of quality, words of objects and action. Thus, the adequacy of the translation assessed based on the perspective of pragmatic accuracy.

This article specifically discusses the translation of modality and its translation quality assessment and aims to explore their construct. The questions addressed in this article are as follows:

1. What are the translation quality of modality marker in Translated Novel Riordan's The Blood of Olympus in terms of accuracy?

2. What are the translation quality of modality marker in Translated Novel Riordan's The Blood of Olympus in terms of acceptability?
Modality is the intermediate degree between 'yes' to 'no' that is the notion of 'necessity' and 'possibility.' In each case the distinction of the notion is pragmatic: a context-dependent. The selection of contextual information taken as relevant can be influenced by the nature of the sentence itself [1].

Context is subjectivity, but it is possible to show that the contextual aspects of modality are not purely to do with subjectivity because objective modality also involves context. It is widely understood that the English modals are subjective that is that they encode a speaker's eye view- and that part of their grammaticalization has involved their becoming increasingly subjective [12][13].

There are two classes of modality namely epistemic and deontic. The former relates to the level of certainty of a proposition's truth while the latter expresses the language user's attitudes in society such as, duty, morality, laws and rules. In deontic modality, language users express their attitude along the permission to obligation dimension as the following examples:

a. You can ride my bike anytime you like

b. The consul could have been more helpful

c. You should send him an email

d. Tax forms must be submitted by the end of September. [4]

Adding modal verb, enhance the quality of exchange. This is needed in daily communication to maintain the harmony or to avoid impoliteness. One needs a face or 'self-image'. There are two ways in threatening Face whether positive or negative. Positive politeness emphasizes the positive status of the hearers while the negative one mitigates the effect of belittling expressions such as "help me to move this table" [2] this paper will employ the translated text to see the cross cultural politeness through modality markers. Besides, the equivalence of source language and target language will be determined.

\section{MethodS}

Modal operator plays an important role to change sense of utterances. This strategy relates to the idea of politeness. Leech proposes seven principles of politeness. They are The Tact Maxim, Generosity Maxim, The Praise Maxim, The Modesty Maxim, The Agreement Maxim, The Sympathy Maxim and Consideration Maxim. The following will exploit how modal operators have a sense of politeness. This classification of 
modality based on the Halliday category of modal value, that is high, medium, and low. The data are the utterances that produced by the characters in the novel Riordan's The Blood of Olympus. To obtain the given data, the source Text (ST) and the target text (TT) gaining meaning of necessity and possibility are collected in order to examine the equivalence. By doing so, the accuracy and acceptability of the translated modality are being assessed.

\section{RESULTS AND DISCUSSION}

Governments often confront to their citizens since their policies injustices of social and political consequences for civil rights. As a reaction, the civil employ a dual strategy of direct action combined with nonviolent resistance. The former causes crisis situation while the latter lessen the conflict. One of the champion of civil right movements was led by Martin Luther King who delivered his speech's I have a dream, in front of Lincoln Memorial Marching on Washington for job and freedom by employing the method of nonviolent resistance in 1963.

This humble civil movement received good response from the government in solving the crisis situation. Many devices are used to state something that is wrong in nonviolent resistance, one of them is modality which lessen the conflict. Furthermore, in transactional exchanges, what a speaker's or author's 'agenda' is hinted in modal verbs, such as, "You must apologize", "You can come in now" and "Martians could be green". They indicate obligation, permission and merely possibility in respectively. The carriers of modality are a set of auxiliary verbs called modals, will, would, can, could, may, might, shall, should, must and ought to and other expressions are possibly, probably, have (got) to, need to and be able to [4].

The selected data are arranged in the form of table. The left column are the utterances of characters which add the modal verbs such as sure, must and will in the original novel of Riordan's The Blood of Olympus, then it is called as source text (ST), meanwhile the right column are the translated utterances as a target text (TT). In addition, the number in brackets in end of utterances showing the page of the novel.

\section{High Value}

For epistemic modality, high means a high probability of the truth of the proposition. While deontic modality points to this value as a high obligation. The members are 'must', 'ought to', 'need', 'have to', and 'is to'. Another is 'it is certain that'
Table 1: High Value of Modal Operator

\begin{tabular}{|c|c|c|}
\hline & SL & TL \\
\hline 1 & $\begin{array}{l}\text { You sure this is the } \\
\text { right hill?(p.6) }\end{array}$ & $\begin{array}{l}\text { Kau yakin ini bukit } \\
\text { yang benar?( } 4 \text { ) }\end{array}$ \\
\hline 2 & You must stay (25) & $\begin{array}{l}\text { Kau harus diam } \\
\text { disini }(24)\end{array}$ \\
\hline 3 & $\begin{array}{l}\text { If you come from } \\
\text { gaea, you must know } \\
\text { we are here...(21) }\end{array}$ & $\begin{array}{l}\text { Jika kau datang atas } \\
\text { perintah Gaea, kau } \\
\text { seharusnya } \\
\text { bahwa kami ke } \\
\text { sini...(20) }\end{array}$ \\
\hline 4 & $\begin{array}{l}\text { We'll need you to be } \\
\text { ready again by } \\
\text { nighfall. }(54)\end{array}$ & $\begin{array}{l}\text { Kau harus sudah } \\
\text { kembali siap senja } \\
\text { nanti(54) }\end{array}$ \\
\hline 5 & $\begin{array}{l}\text { Hey..."you need } \\
\text { sleep too. }(57)\end{array}$ & $\begin{array}{l}\text { Hei,"..."kau juga } \\
\text { butuh tidur.(58) }\end{array}$ \\
\hline 6 & $\begin{array}{l}\text { Octavian smiled. "I } \\
\text { believe in second } \\
\text { chances. You've } \\
\text { responded to my } \\
\text { call...(65) }\end{array}$ & $\begin{array}{l}\text { Aku percaya, siapa } \\
\text { saja berhak mendapat } \\
\text { kesempatan } \\
\text { kedua.kau sudah } \\
\text { menjawab seruanku } \\
\text {...(66) }\end{array}$ \\
\hline
\end{tabular}

Tact maxim is minimizing cost to hearer and maximizing benefit to hearer. This maxim is applied in Searle's speech act, commissives and directives called by Leech as impositives. Commissives is found in utterances that express speaker's intention in the future action. Then, Directives/ impositives are expressions that influence the hearer to do action. The speakers uttered (2), (3), and (5) maximize benefit to the hearers. Since the speakers intent an action for future.

However, the utterance (3) is less accurate. Since the target language change the value of modality from high to medium from "harus" becomes "seharusnya". Similarly, utterance (4) change the intention of the speaker of source language from generosity maxim is tranferred into tact maxim by changing the pronoun 'we' (the plural first person) become 'kau' (the singular second person)

\section{Median value}

For this level can be distinguished from high and low values can be distinguished by their behavior with negatives. Modal operators are 'will', 'would', 'shall', and 'should'. Also, 'It is probable that' is categorized into median. 
Table 2: Median Value of Modal Operator

\begin{tabular}{|l|l|l|}
\hline & SL & TL \\
\hline 7 & $\begin{array}{l}\text { You 'd think that } \\
\text { would keep a guy } \\
\text { down. What about } \\
\text { all the } \\
\text { others?(p.12) }\end{array}$ & $\begin{array}{l}\text { Meski sudah dipanah, } \\
\text { ternyata dia tetap cari- } \\
\text { cari masalah. Yang lain } \\
\text { bagaimana?(10) }\end{array}$ \\
\hline 8 & $\begin{array}{l}\text { We don't need } \\
\text { you to run } \\
\text { messages for us } \\
\text { lilke in the old } \\
\text { days. Certainly you } \\
\text { aren't } \\
\text { fighter...(p.17) }\end{array}$ & $\begin{array}{l}\text { Kami } \\
\text { membutuhkanmu } \\
\text { untuk mengantarkan } \\
\text { pesan seperti dulu. Kau } \\
\text { jelas-jelas bukan } \\
\text { seorang petarung...(16) }\end{array}$ \\
\hline 9 & $\begin{array}{l}\text { Why should you } \\
\text { be welcome among } \\
\text { us?'(p.20) }\end{array}$ & $\begin{array}{l}\text { Untuk apa kami mesti } \\
\text { menerimamu di antara } \\
\text { kami?(18) }\end{array}$ \\
\hline 10 & $\begin{array}{l}\text { Why should you } \\
\text { welcome } \\
\text { me?'(p.20) Jason } \\
\text { growled }\end{array}$ & $\begin{array}{l}\text { Untuk apa kalian } \\
\text { mesti menerimaku?" } \\
\text { jason menggeram(19) }\end{array}$ \\
\hline 11 & $\begin{array}{l}\text { Maybe you should } \\
\text { muzzle your } \\
\text { roman(26) }\end{array}$ & $\begin{array}{l}\text { Mungkin sebaiknya } \\
\text { kau bungkam si orang } \\
\text { Romawi ini."(25) }\end{array}$ \\
\hline 12 & $\begin{array}{l}\text {.would you return } \\
\text { home like...(31) }\end{array}$ & $\begin{array}{l}\text { Akankah kau pulang } \\
\text { ke rumah seperti .... }\end{array}$ \\
\hline 13 & $\begin{array}{l}\text { I suppose we'll } \\
\text { just kill you.(35) }\end{array}$ & $\begin{array}{l}\text { Kalau begitu, kami } \\
\text { bunuh saja kau."(34) }\end{array}$ \\
\hline 14 & $\begin{array}{l}\text { I'll lend you my } \\
\text { strength(50) }\end{array}$ & $\begin{array}{l}\text { Akan kupinjami kau } \\
\text { kekuatan(50) }\end{array}$ \\
\hline 15 & $\begin{array}{l}\text { You should rest, } \\
\text { Kau sebaiknya }\end{array}$ \\
\hline
\end{tabular}

Agreement maxim is showed by utterance (7). The speaker minimized disagreement with the hearer by adding "you think". While, generosity maxim are in utterances (8), (13), (14),(16), and (17). While utterance (18) showed consideration maxim.

Concerning to the quality of the translated text, there are some changes the speaker's intention of source language and level of modality. Utterance (7), the target language didn't address to the hearer by omit pronoun 'you' (singular second person) and directly to the third person i.e. 'the guy'. It seems that the existence of the hearer was ignored. Another case is in utterance (9). The pronoun 'you' (singular second person) in source language transferred into 'kami' (plural first person). The accuracy is fair.

\section{Low value}

For epistemic modality, high means a low probability of the truth of the proposition. While deontic modality points to this value as a low obligation. The members are 'may', 'might', 'can', and 'could'. The others are 'it is possible that' and 'it is unlikely that'
Table 3: Low Value of Modal Operators

\begin{tabular}{|l|l|l|}
\hline 19 & SL & TL \\
\hline 20 & $\begin{array}{l}\text { It's possible that's } \\
\text { it?(29) } \\
\text { why we were } \\
\text { pulled off } \\
\text { course.(55) }\end{array}$ & $\begin{array}{l}\text { Tidak bisakah kau } \\
\text { merasakanya?(29) } \\
\text { sebabnya kita ditarik ke } \\
\text { luar jalur.(55) }\end{array}$ \\
\hline 21 & $\begin{array}{l}\text { Can you keep } \\
\text { them at bay?"she } \\
\text { asked(55) }\end{array}$ & $\begin{array}{l}\text { Bisa kau menghalau } \\
\text { mereka? } \\
\text { Reyna(56) }\end{array}$ \\
\hline 22 & $\begin{array}{l}\text {-.But if I may, } \\
\text { those charges were } \\
\text { unproven. I am a anya } \\
\text { loyal Roman."(65) }\end{array}$ & $\begin{array}{l}\text { Tapi, jika boleh saya } \\
\text { katakan.tuduhan idu } \\
\text { tidak terbukti. Saya } \\
\text { tetap warga Roma yang } \\
\text { setia.(66) }\end{array}$ \\
\hline 23 & $\begin{array}{l}\text { I may have a little } \\
\text { job for you-(66) }\end{array}$ & $\begin{array}{l}\text { Sebentar lagi mungkin } \\
\text { ada pekerjaan kecil } \\
\text { untukmu(67) }\end{array}$ \\
\hline 24 & We can tallk more & Kita bisa bicara lebih \\
\hline
\end{tabular}

It is first necessary to distinguish between the negation of the modal and the negation of proposition as in (19) and (21)

'Can't you sense it?

Can you keep them at bay? She asked.

For the first is the speaker minimized disagreement with the hearer by negating modal. Meanwhile, the second is the directive/ impositive utterance. This utterance is spoken to ask the hearer keeping down the enemy at bay. The speaker uses indirect utterance to be more polite and minimizing cost to the hearer. This utterance implies that keeping them at bay is benefit to the hearer.

Most of the target languages transferred the voice of speaker appropriately. Except the utterance (26), the low possibility of 'might' became 'bisa-bisa' which is showing the necessity rather than the possibility. From deontic becomes epistemic modality. And this makes the changes of speaker's intention.

\section{CONCLUSION}

Among three value of modality, high, median and low, the equivalence of modal verb tend to change the voice of speaker. As a consequently, the shift from one politeness maxim into another occurred. Interestingly, the equivalence of the translations from source language into target language worked in low value. Which possibility is highest. It represents Indonesian tend to deontic rather than epistemic. The subjectivity dominates in the society.

\section{REFERENCES}

[1] Biber, D. (1995) Dimensions of Register Variation.: A Cross-Linguistic Comparison. Cambridge: A Cambridge Univeersity Press.

[2] Cruse, D. Alan.(2000). Meaning in Language: An Introduction to Semantics and Pragmatics.New York: Oxford University Press.

[3] Cutting, John. (2010). Pragmatics and Discourse: A resourse book for students.NY: Routledge.

[4] Griffiths, Patrick. (2006). An Introduction to English Semantics and Pragmatics. Great Britain:Edinburgh University Press Ltd. 
[5] Halliday, M.A.K., (1994). An Introduction to Functional Grammar. (2nd ed). London: Edward Arnold.

[6] Halliday, M.A.K. and Matthiessen, C., (2004). An Introduction to Functional Grammar. (3rd eds). London: Hodder Education.

[7] House, Juliane. (2015). Translation Quality Assessment. New York: Routledge.

[8] Nababan, M.R.(2007). "Aspek Genetik, Objektif, and Afektif dalam Penelitian Penerjemahan.”Linguistika 14.(26),15-23

[9] Olaniyan, Kazeem K.,\& Adeniji, A. (2015). MODALITY IN STATEMENT OF OBJECTIVES IN ARTS-BASED RESEARCH ARTICLE ABSTRACTS in British Journal of English Linguistics Vol.3, No.1 pp.42-51, March 2015

[10] Riordan, Rick. (2014). The Blood of Olympus. USA: Disney*Hiperion

[11] Riordan, Rick. (2014). The Blood of Olympus. Transl. Reni Indardini. Jakarta: PT Mizan Fantasi
[12] Sweetser, E,. (1990). FRom Etymology to Pragmatics: Metaphorical and Cultural Aspects of Semantic Structure. Cambridge: Cambridge University Press.

[13] Traugott, Elizabeth C. (1989). "On the Rise of Epistemic Meanings in English: An Examples of Subjectivication in Semantic Change" Language Vol. 65 No. 1 (Mar., 1989), pp. 31-55

[14] Wardhaugh, Ronald. (1995). An Introduction to Sociolinguistics.(2nd.ed).UK: Blackwell Publishers.

[15] P. Newmark, A Textbook of Translation. 1988. 